\title{
LEADER - EX-POST EVALUATION OF THE DELIVERY MECHANISM LEADER - EX-POST HODNOTENIE
IMPLEMENTAČNÉHO MECHANIZMU
}

Monika BUMBALOVÁ - Ivan TAKÁČ -

Martin VALACH - Jela TVRDOŇOVÁ*

\section{Introduction}

The concept of integrated rural development has, within the last decade, become one of the key pillars, on which the European Union (EU) builds up the implementation of its developing programmes. The LEADER approach (French acronym for Liaison Entre Actions de Développement de le Économie Rurale) can be seen as a carrier of this concept. The approach is primarily defined by 7 key features, which are: area-based local development strategies, bottom-up elaboration and implementation of strategies, local publicprivate partnerships - local action groups, integrated and multisectoral actions, innovation, cooperation and network$\operatorname{ing}^{(1)}$.

Legal baseline for the approach at the EU level is laid down in the Council Regulation 1698/2005, which suggested set of measures organised into axis in order to keep balance

EUROPEAN COMMISSION. 2006. LEADER Approach - basic guidlines [online], [cit. 2015-01-21]. ISBN 92-79-02058-7. Available online: http://ec.europa.eu/agriculture/rur/leaderplus/pdf/ library/methodology/leader_approach_sk.pdf.

\section{Abstract (EN)}

LEADER approach represents one of the basic pillars of current rural development policy implemented at the European level. Logical foundation of the approach is based on 7 key features, which should be horizontally presented throughout the whole delivery mechanism. That is why the presented paper is oriented on answering the research question: to what extent was delivery mechanism of LEADER (at the level of managing authority and local action groups) during the programming period 2007-2013 supporting the implementation of 7 features of LEADER approach. In order to fulfil the stated objective there must be individual steps of delivery mechanism defined at both levels, consequently all the features of LEADER approach were described and the criteria of success - benchmarks were determined. Mutual linking of these steps resulted in creation of an implementation matrix what represents a visual outcome of the study.

\section{Keywords (EN)}

LEADER, key features, delivery mechanism

Slovak University of Agriculture in Nitra, Slovakia between competitiveness of agricultural businesses, environmental protection and social dimension of rural development.

In the Slovak conditions, the Ministry of Agriculture and Rural Development, the Agricultural Paying Agency and local action groups (LAGs) ensure the implementation of the LEADER approach. Presence of the developing potential in the area, strengthened by local initiatives such as local action groups, is a basic precondition for LEADER implementation $^{(2)}$. LAGs in fact work as representatives of the approach in a concrete territory and they mediate the local development through the Local Development Strategy (hereafter refer to as strategy). Local partnership in form of LAG represents a practical element of administration organization, which is created in accordance with the idea of common gov-

(2) VOLK, A. - BOJNEC, Š.. 2014. Local action groups and the LEADER co-financing of rural development projects in Slovenia. In Agricultural Economics, vol. 60, no. 8, pp. 364-375. ISSN 0139570X

\section{Abstrakt (SK)}

Prístup LEADER je jedným zo základných pilierov súčasnej politiky rozvoja vidieka realizovanej na európskej úrovni. Logický základ prístupu LEADER je postavený na 7 klúčových znakoch, ktoré by mali byt' prítomné prierezovo v rámci celého implementačného procesu. Preto cielom príspevku bolo zodpovedanie výskumnej otázky: do akej miery implementačný mechanizmus programu LEADER (na úrovni riadiaceho orgánu aj miestnych akčných skupín) v programovom období 2007-2013 podporoval dodržiavanie siedmych základných znakov programu?" Pre naplnenie ciela príspevku bolo nevyhnutné určit jednotlivé kroky implementačného procesu na oboch úrovniach, následne popísat' jednotlivé znaky a definovat' kritériá úspechu - benchmarky. Vzájomným prepojením predchádzajúcich krokov bola vytvorená implementačná matica, tvoriaca vizuálny výstup štúdie.

\section{Klưčové slová (SK)}

LEADER, klúčové znaky, implementačný mechanizmus 
Table 1: Delivery Mechanism of the LEADER Approach at the RDP Level

\begin{tabular}{|c|c|}
\hline Situational analysis & $\begin{array}{l}\text { Data collection about the rural areas, the rate of growth, most important production activities, national } \\
\text { priorities and relevant strategies for the support of sustainable development }\end{array}$ \\
\hline \multirow[t]{2}{*}{ National strategy } & $\begin{array}{l}\text { Submission of the National Strategic Plan for the years 2007- } 2013 \text { for identification of priorities for sup- } \\
\text { port from the ERDF, }\end{array}$ \\
\hline & submission of Rural Development Programme of SR 2007 -2013 \\
\hline \multirow{5}{*}{$\begin{array}{l}\text { Administration } \\
\text { guidance }\end{array}$} & Measures for axis 4 (and implementation of measures of axis 3 trough axis 4), \\
\hline & financial allocation, \\
\hline & conditions for selection of LAGs, \\
\hline & definition of legal and administrative framework, \\
\hline & definition of rights and duties of all actors: LAG, APA, final beneficiaries \\
\hline Guidance upgrade & Changes of the guidance (legal, administrative, financial and programme) \\
\hline Awareness creation & $\begin{array}{l}\text { Ministry and Paying Agency spread the information about the Guidance for administration through } \\
\text { regional workshops, leaflets, webpages etc. }\end{array}$ \\
\hline Capacity building & $\begin{array}{l}\text { Training for the representatives of the partnerships, which plan to apply for the LAG statute, mainly about } \\
\text { the selection criteria, strategy creation, financial, legal and technical support for the programme }\end{array}$ \\
\hline \multirow[t]{2}{*}{ Call for proposals } & $\begin{array}{l}\text { Call for proposals (in accordance with the national Guidance) with specific information about budget, } \\
\text { selection criteria, planned number of LAGs, planned percentage of territory covered by the developing } \\
\text { strategies, eligibility, reasoning for the territory selection, }\end{array}$ \\
\hline & time framework \\
\hline \multirow{4}{*}{ Proposals evaluation } & Selection of LAGs, \\
\hline & criterion for partnership \\
\hline & criterion for strategy, \\
\hline & criterion for the territory. \\
\hline \multirow{3}{*}{ Contract signing } & Official contract between APA and LAG (including the developing strategy and budget), \\
\hline & agreement on usage of the public resources, \\
\hline & the contract is signed for a 7 years period. \\
\hline Contract upgrade & Contract can be upgraded each year according to the needs of the territory. \\
\hline LAG monitoring & Performed annually by APA. \\
\hline \multirow{2}{*}{ Evaluation } & Performed by managing authority (MA), \\
\hline & in Slovak conditions the on-going evaluation of RDP 2007- 2013 was performed \\
\hline
\end{tabular}

Source: own processing

ernance of the public, non-profit and private sector ${ }^{(3)}$. The same author also stated that a successful implementation of the multisectoral integration is a result of several preconditions and external influences such as favourable institutional and administrative context, successful and diversified local economy, viable, dynamic and representative partnership and strategic orientation on the action plans. LEADER is therefore perceived as an instrument of integrated approach towards the development of the rural areas, which is primarily based on the partnership of the local actors coming from different sectors. The objective of the approach can be defined as "the improvement of the quality of life in the rural regions, evaluation of the natural and cultural heritage as well as enhancing the economic activities in the rural areas ${ }^{(4)}$. LEADER can be also seen as a tool for stimulation of pro-

(3) ZAJDA, K. 2014. Problems of functioning of Polish local action groups from the perspective of the social capital concept. In Eastern European Countryside, no. 20/2014, pp. 73 - 97. ISSN 23008717.

(4) Rural Development Programme SR 2007 - 2013.
Fig. 1: Evaluation Framework for the Delivery Mechanism of the LEADER Approach

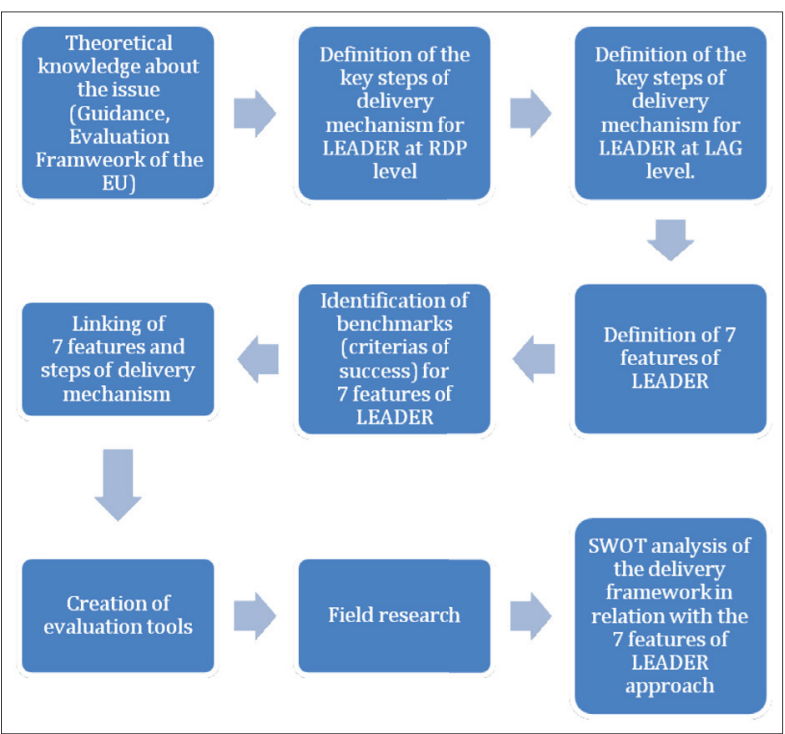

Source: Tvrdoñová (2014) 


\section{Agrárne

Table 2: Delivery Mechanism of the LEADER Approach at the Local Action Group Level

\begin{tabular}{|c|c|}
\hline \multirow{2}{*}{ Partnership creation } & Creation of links between local structures, MA and APA, \\
\hline & proportionality of subjects from private and public sector \\
\hline Creation of LAG bodies & $\begin{array}{l}\text { General assembly, managing board, chairman, vice-chairman, selection committee, moni- } \\
\text { toring committee, control committee. }\end{array}$ \\
\hline \multirow{2}{*}{ Strategy design and approval } & Need for ensuring participation of different actors, \\
\hline & raising awareness about the rural development \\
\hline \multirow{5}{*}{ Call for proposals } & Local capacity building, \\
\hline & setting up criteria for project selection, \\
\hline & selection of activities for financing through the local strategy, \\
\hline & $\begin{array}{l}\text { ensure information of all actors about the call for proposals, supported measures, criteria } \\
\text { and the process of project selection, }\end{array}$ \\
\hline & technical support for the potential final beneficiaries. \\
\hline $\begin{array}{l}\text { Evaluation by the selection committee/ } \\
\text { project selection }\end{array}$ & $\begin{array}{l}\text { LAG manager and the members of the selection committee evaluate the eligibility of the } \\
\text { proposed projects before there are sent for evaluation to APA. }\end{array}$ \\
\hline Project approval by the APA & $\begin{array}{l}\text { Projects are evaluated by the paying agency, while LAGs are passive actors at this stage of } \\
\text { the evaluation process }\end{array}$ \\
\hline $\begin{array}{l}\text { Announcement of the decision of APA } \\
\text { to the final beneficiaries }\end{array}$ & LAG announces the decision to the final beneficiaries \\
\hline Contract signing & Contract signing is done among the paying agency and the final beneficiary \\
\hline \multirow[b]{2}{*}{ Strategy upgrade } & Once a year, the LAG can ask for the strategy upgrade, \\
\hline & $\begin{array}{l}\text { at the LAG level, the upgrade is approved by the general assembly and it is submitted to } \\
\text { the paying agency. }\end{array}$ \\
\hline Monitoring and evaluation & Project implementation is monitored and evaluated by LAG and also by the paying agency \\
\hline
\end{tabular}

Source: own processing

cesses in the rural environment and economy and not as a tool for support investments ${ }^{(5)}$. Supporting this idea, LEADER should be rather seen as a method for mobilisation and implementation of the rural development in the local rural communities, than a strict set of rules, which should be applied ${ }^{(6)}$. In comparison with other measures of the EU rural policy, in case of LEADER, stronger emphasis is put on the ideological and symbolical importance of the approach than on finan$\mathrm{cial}^{(7)}$. This philosophy is partially supported by the distribution of finances from the European Rural Development Fund (ERDF), as only $7 \%$ of the total budget was allocated for the LEADER approach in the programming period 2007- 2013. The mentioned arguments are the reasons why in the LEADER implementation, attention should be paid to correct setting of the delivery mechanism, which ensures maintaining of the fundamental features of the approach. The presented paper reacts on this topic through an ex-post evaluation.

(5) SHUCKSMITH, M. - THOMSON, K. J. - ROBERTS, D. 2005. The CAP and the regions - Territorial impact of the common agricultural policy. Oxfordshire: CABI Publishing.

(6) HRABOVSKÁ, Z. - VAL'OVSKÁ, Z. 2014. Regionálna ekonomika a rozvoj II. (Regional Economics and Development II.) (selected chapters). Košice: Univerzita Pavla Jozefa Šafárika v Košiciach, pp. 234. ISBN 78808152224

(7) JANKOVIČ,D. 2012.Territorial Approaches to Regional Rural Development. In Economics of Agriculture, no. 4/2012, pp. 675688. UDC: $332.122: 338.43$

\section{Material and Method}

The objective of the paper is to answer a research question which is stated as follows: „To what extent was delivery mechanism at Rural Development Programme (RDP) and LAG level in the programming period 2007- 2013 supporting the implementation of 7 features of Leader approach?"

The creation of the evaluation framework for the delivery mechanism for the LEADER approach based on the methodology of

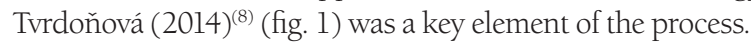

Theoretical knowledge about the studied area was gained from the relevant information resources including legislative framework. Within the second and third steps, the key steps of the delivery mechanism of the LEADER approach were identified at the programme level and LAG level.

Definition of the seven LEADER features was one of the preconditions for the analysis. Consequently, each of the features was attributed „benchmarks" (criteria of success). Their presence represents the optimal state of implementation. Linking of the seven features with the steps of delivery mechanism lead to creation of so-called implementation matrix.

Theoretical testing of the benchmarks was performed in

(8) TVRDOŇOVÁ, J. 2014. The Case study: „Ex post evaluation of Leader approach delivery" - Final report [online], [cit. 2015-0112]. Available online: http://www.fesrr.uniag.sk/tl_files/fesrr/ documents/IMRD/IMRD\%20CS\%202014\%20-\%20Final\%20 Report.pdf. 
form of interviews at the LAG level (managers, members of the executive board, final beneficiaries, members of the selection committees etc.). The analysis of the evaluation results led to formulation of conclusions and recommendations.

\section{Steps of the Delivery Mechanism}

Delivery mechanism of the LEADER approach, from its beginning to the monitoring and evaluation of the allocation of finances for the final beneficiaries, could be divided into two main levels which are the programme level (RDP) and the level of the local action groups (LAG). There are central bodies, directly involved in the activities, defined at each level, however, the individual activities are interlinked by mutual relations and it is not always possible to clearly separate them from each other. Tables 1 and 2 contain the identified steps at both levels together with description of the individual activities.

\section{LEADER Features and Benchmark Characteristics}

Leader approach put emphasis on the usage of local initiatives in order to improve the developing potential of the rural regions and also on strengthening the awareness creation at the local level. This approach is based on 7 main features, to which appropriate benchmarks are attributed.

\section{Area-based local development strategies}

Local development strategies describe the basic features which differentiate the area from other areas and based on which, the local inhabitants associate themselves with that area. Not only administrative borders belong to such features, but also:

- natural potential of the territory e.g. natural resources, climate, relief etc.,

- territorial identity representing social features which are defined by generations, therefore they are not easily changeable, which differentiate the territory from other territories, e.g. culture, norms, traditions, language, religion, etc.,

- socio-economic specificity given by the structure of economic activities in the territory,

- current infrastructure and administrative organization of the territory is based on historical foundations,

- demography of the territory (structure according to age, gender, marital status, income, education),

- level of education and information which plays key role in capacity building during the local strategy design,

- social contacts and networks enabling linkages within and between the regions.

Benchmarks

Strong identity of local inhabitants.

Territorial homogeneity regarding natural conditions, common history, language, customs and interests enabling cooperation, definition and achievement of common objectives.

\begin{tabular}{|l|}
\hline $\begin{array}{l}\text { Planned and implemented socio-economic activities are } \\
\text { derived from the sector base existing in the territory. }\end{array}$ \\
\hline Favourable demographic structure of the territory. \\
\hline Existing communication tools and methods. \\
\hline Strong links within the region and between regions. \\
\hline $\begin{array}{l}\text { Emigration and immigration within the territory but also } \\
\text { outside of the territory. }\end{array}$
\end{tabular}

Bottom-up elaboration and implementation of strategies Capacity building represents the basic factor of the approach. The approach uses the knowledge existing in the territory and it enables all actors to get involved into developing and decision-making process. The community manages gaining and distribution of the internal financial resources.

\begin{tabular}{|l|}
\hline Benchmarks \\
\hline Local actors with adequate training hold leading positions. \\
\hline $\begin{array}{l}\text { Active involvement of local actors into all steps of decision- } \\
\text { making process. }\end{array}$ \\
\hline Rate of usage of local resources. \\
\hline $\begin{array}{l}\text { Development strategy takes into account interests of all } \\
\text { groups and sectors. }\end{array}$ \\
\hline $\begin{array}{l}\text { Composition of actors participating at the decision- making } \\
\text { process reflects heterogeneity of the local inhabitants. }\end{array}$ \\
\hline $\begin{array}{l}\text { Clear selection criteria applied during the strategy implemen- } \\
\text { tation. }\end{array}$ \\
\hline
\end{tabular}

Local public-private partnerships (local action groups) Local public-private partnership supports common usage of knowledge, experience and resources between private, public and civic sector, within the community. There is a balanced ratio within these partnerships regarding number of votes, power, resources and cooperation. Partnership decides about the orientation and content of the local development strategy.

\begin{tabular}{|l|}
\hline Benchmarks \\
\hline $\begin{array}{l}\text { Partnership consists maximum } 50 \% \text { of public sector and } \\
\text { minimum } 50 \% \text { of private and civic sector. }\end{array}$ \\
\hline $\begin{array}{l}\text { Representatives of all three sectors are involved in the deci- } \\
\text { sion-making process. }\end{array}$ \\
\hline $\begin{array}{l}\text { Implementation of common (mutually interlinked) horizon- } \\
\text { tal topics of public-private partnership. }\end{array}$ \\
\hline
\end{tabular}

\section{Integrated and multisectoral actions}

Integrated and multisectoral partnerships involve combination of different sectorial orientations (economic, social, cultural, ecological) in order to reach a holistic view of a concrete problem in the territory. Actions and projects included in the local strategies should be linked and coordinated as a coherent unit.

\begin{tabular}{|l|}
\hline Benchmarks \\
\hline Local development strategy supports the synergies of inter- \\
ests and needs of different sectors operating in the territory \\
(geographical, social and economic).
\end{tabular}


Strategy implementation ensures common effort of all sectors and groups in development of the region.

\section{Networking}

Networking represents dissemination of information through linkages of individuals, LEADER groups, rural areas, administrations and organizations involved in the rural development. Networking is a mediator for transmission of best practices and spreading of innovation. Networking is implemented at the institutional level (EU level), at national, regional and local level.

\begin{tabular}{|l|}
\hline Benchmarks \\
\hline Actors at all three levels are clearly identified. \\
\hline $\begin{array}{l}\text { Active communication and awareness among individual } \\
\text { actors. }\end{array}$ \\
\hline $\begin{array}{l}\text { All the local actors are involved in the coordination of activi- } \\
\text { ties, which concern them. }\end{array}$ \\
\hline $\begin{array}{l}\text { Existence of feedback during the strategy implementation } \\
\text { (project, activities). }\end{array}$ \\
\hline
\end{tabular}

\section{Cooperation}

Cooperation enables LAG to fulfil those objectives, which could not be reached individually and which go beyond the LAG border. Cooperation increases the utility of implemented projects and activities. Effectiveness is ensured by economical usage of resources. Cooperation is based on trust.

\begin{tabular}{|l|}
\hline Benchmarks \\
\hline $\begin{array}{l}\text { Mutual communication of all partners within a transparent } \\
\text { environment. }\end{array}$ \\
\hline $\begin{array}{l}\text { Coordination among actors leads to effective and optimal } \\
\text { allocation of resources. }\end{array}$ \\
\hline $\begin{array}{l}\text { The strategy allows for linking of sectors, localities and } \\
\text { regions. }\end{array}$ \\
\hline $\begin{array}{l}\text { Strong social capital is presented within the system and } \\
\text { between different ones (trust). }\end{array}$ \\
\hline Cooperation strengthens capacity building. \\
\hline
\end{tabular}

\section{Innovation}

Innovation includes transmission and adaptation of innovation, which are developed elsewhere, modernisation of traditional know-how forms, or searching for new solutions in case of continuous problems of rural areas. Innovation works only in the case when positive effects are seen in the given situation and there is stimulation for creation of new ideas.

\begin{tabular}{|l|}
\hline Benchmarks \\
\hline Decision-making process in LAG is free and flexible. \\
\hline Innovative management of local resources. \\
\hline New products based on innovative activities. \\
\hline $\begin{array}{l}\text { New technologies are introduced in those areas where they } \\
\text { had not been presented before. }\end{array}$ \\
\hline
\end{tabular}

External knowledge is spread among the groups and individuals within a region and between regions.

\section{Creation \\ of implementation matrix}

Implementation matrix is based on mutual interlinking of individual steps of delivery mechanism and features of the LEADER approach. Matrix represents graphic outcome of the study, which horizontally captures the presence (or absence) of key features, defined based on the success criteria - benchmarks, during the delivery mechanism (Table 3 and 4).

Out of all key features, "Bottom-up elaboration and implementation of strategies" and "Cooperation" are the features most frequently reflected in the delivery mechanism, with approximately same frequency at both levels. Contrary, the least frequent features are "local public-private partnerships" and "networking". The firstly mentioned feature is more absent at the RDP level and the second one paradoxically at the LAG level.

\section{Conclusions and Recommendations}

Due to the fact that the LEADER approach is composed of seven key features, there is no unified evaluation or recommendation for its implementation. Therefore, the conclusions and recommendations were formulated individually for each of the feature.

When assessing the feature „Area-based local development strategies", the way the LEADER approach reflects needs; heterogeneity and interests of the given territory were observed. LEADER supports territorial cohesion and territorial identity and it is a useful tool for integration of different visions, opinions and interests in order to improve the effectiveness of rural development. LAG is able to identify real needs and expectations of local actors, even though their representation in the LAG could be improved. Limited access to qualified human resources prevents LAGs from complex and effective reactions on the territory needs. LAGs mediate mostly allocation of financial means, which are spent on revitalization of public property (cultural houses, roads, bridges, bus stops) instead of investments to strategic activities, which would strengthen the local development. This fact contributes to the distorted picture about the LEADER approach, which demotivates potential partners from the private and civil sector.

More attention should be paid to the widening of portfolio of eligible measures and moving of finances from other axis to LEADER and searching for other resources, which according to MA and APA could be helpful in application of territorial cohesion. It is very important to continue in supporting the activities, which strengthen the common identity and lead to common objectives and to preserve concentration of local resources in order to maintain sufficient support for development of local capacities. It is also necessary to analyse 
Table 3: Implementation Matrix at the RDP level

\begin{tabular}{|c|c|c|c|c|c|c|c|}
\hline \multicolumn{8}{|c|}{ Features of LEADER } \\
\hline & $\begin{array}{l}\text { Area-based } \\
\text { local de- } \\
\text { velopment } \\
\text { strategies }\end{array}$ & $\begin{array}{l}\text { Bottom-up } \\
\text { elaboration } \\
\text { and imple- } \\
\text { mentation } \\
\text { of strategies }\end{array}$ & $\begin{array}{l}\text { Local Pub- } \\
\text { lic- private } \\
\text { partner- } \\
\text { ships }\end{array}$ & $\begin{array}{c}\text { Integrated } \\
\text { and mul- } \\
\text { tisectoral } \\
\text { actions }\end{array}$ & Innovation & $\begin{array}{l}\text { Coopera- } \\
\text { tion }\end{array}$ & Networking \\
\hline \multicolumn{8}{|c|}{ Delivery mechanism RDP level } \\
\hline Situational analysis & $\mathrm{x}$ & & & & & & \\
\hline National strategy & & $\mathrm{x}$ & & & & & \\
\hline $\begin{array}{l}\text { Guidance for administra- } \\
\text { tion }\end{array}$ & $\mathrm{x}$ & $\mathrm{x}$ & $\mathrm{x}$ & $\mathrm{x}$ & $\mathrm{x}$ & $\mathrm{x}$ & $\mathrm{x}$ \\
\hline Guidance upgrade & & $\mathrm{x}$ & & & & & \\
\hline Awareness creation & $x$ & & & $\mathrm{x}$ & & & \\
\hline Capacity building & $\mathrm{x}$ & & & & $\mathrm{x}$ & $\mathrm{x}$ & \\
\hline Call for proposals & $\mathrm{x}$ & & & & $\mathrm{x}$ & $\mathrm{x}$ & $\mathrm{x}$ \\
\hline Evaluation of the proposals & & $\mathrm{x}$ & & & $\mathrm{x}$ & & \\
\hline Contract signing & & & & & & $\mathrm{x}$ & \\
\hline Contract update & & & & $\mathrm{x}$ & & & $\mathrm{x}$ \\
\hline Monitoring LAG & $\mathrm{x}$ & $\mathrm{x}$ & & & & $\mathrm{x}$ & \\
\hline Evaluation & & $\mathrm{x}$ & & $\mathrm{x}$ & & & \\
\hline
\end{tabular}

Table 4: Implementation Matrix at the LAG level

\begin{tabular}{|c|c|c|c|c|c|c|c|}
\hline \multicolumn{8}{|c|}{ Features of LEADER } \\
\hline & $\begin{array}{l}\text { Area-based } \\
\text { local } \\
\text { develop- } \\
\text { ment strate- } \\
\text { gies }\end{array}$ & $\begin{array}{l}\text { Bottom-up } \\
\text { elaboration } \\
\text { and imple- } \\
\text { mentation } \\
\text { of strategies }\end{array}$ & $\begin{array}{l}\text { Local } \\
\text { Public - } \\
\text { private part- } \\
\text { nerships }\end{array}$ & $\begin{array}{c}\text { Integrated } \\
\text { and mul- } \\
\text { tisectoral } \\
\text { actions }\end{array}$ & Innovation & $\begin{array}{l}\text { Coopera- } \\
\text { tion }\end{array}$ & Networking \\
\hline \multicolumn{8}{|c|}{ Delivery mechanism LAG level } \\
\hline Partnership creation & & $\mathrm{x}$ & $\mathrm{x}$ & $\mathrm{x}$ & & $\mathrm{x}$ & $\mathrm{x}$ \\
\hline Creation of LAG bodies & $\mathrm{x}$ & & $\mathrm{x}$ & $\mathrm{x}$ & & $\mathrm{x}$ & \\
\hline Strategy design and approval & $\mathrm{x}$ & $\mathrm{x}$ & $\mathrm{x}$ & $\mathrm{x}$ & $\mathrm{x}$ & $\mathrm{x}$ & \\
\hline Call for proposals & $\mathrm{x}$ & & & & & & $\mathrm{x}$ \\
\hline Project selection & & $\mathrm{x}$ & & & & $\mathrm{x}$ & \\
\hline Project approval by the APA & & & & $\mathrm{x}$ & $\mathrm{x}$ & & \\
\hline $\begin{array}{l}\text { Announcement of the decision } \\
\text { of APA to the final beneficiaries }\end{array}$ & & $\mathrm{x}$ & & & & $\mathrm{x}$ & \\
\hline Contract signing & & & & & & $\mathrm{x}$ & \\
\hline Strategy upgrade & & $\mathrm{x}$ & & & & & \\
\hline Monitoring and evaluation & & $\mathrm{x}$ & & $\mathrm{x}$ & $\mathrm{x}$ & & \\
\hline
\end{tabular}

other alternatives for increasing the initial capital, which LAG offers to the private businesses. It is necessary to merge local initiatives when searching for the alternative sources of employment or income.

Support for the subsidiarity principle during the implementation of the LEADER approach is based on the "Bottom-up elaboration and implementation of strategies". Within the LAG, there are different actors participating in the decision-making. However, there is still a room for increasing the level of information about LAG activities and encouraging also non-members for participation. As despite the effort of LAG in spreading the information about strategy and its priorities, there are still some strategic needs in the territory, which are not reflected in the strategy. This situation can have a negative impact on the participation of actors in the decision-making process. Additionally, bureaucratic restrictions of delivery mechanism limit the independence of final beneficiaries and increase their dependence on the LAG management. This situation is also influenced by the fact that the guidance "dictates" character of the supported projects 
and measures, what is partially caused by the fact, that during the identification of national priorities, the feedback from the regions was not taken into account.

LEADER approach played a key role regarding creation of concrete instruments for achievement of developing objectives directly in the territory, but there exist a wide group of decisions, which do not respect the principle of subsidiarity (e.g. beneficiaries are not always included in the strategy design).

All actors (LAG, APA, MA) should continue with dissemination of information by different means. It is very important to organize events, which would contribute to awareness creation about the LAG strategies, needs of the community and the possibilities to participate. Strategic documents adopted at the national level should include measures from other axis of the Common Agricultural Policy, what should lead to increased chances of potential beneficiaries for gaining the finances and technical support from the LAG. Consequently, the local strategy would be more diverse and it would be able to reflect the needs of beneficiaries. National guidance for LEADER should include some binding measures, based on which the LAG would support capacity building with the potential beneficiaries and other actors.

„Local public-private partnership (LAG)“ should create the conditions for effective cooperation of public and private sector during the LEADER implementation. LEADER institutionalizes cooperation of private and public sector what multiplies the effect of public investments. The reason for existence of public-private partnership is often not understood and the participation of private sector is motivated solely by subsidies.

The basic recommendation in this case would be that the public-private partnerships should be based more on the common objectives, than on the finances. More detailed analysis of alternatives for initial capital increase, what LAG offers for local entrepreneurs, would be essential. Linking of local initiatives and creation of conditions for development of alternative resources of employment or incomes is also seemed as inevitable.

Through the „Integrated and multisectoral actions” LEADER should be able to integrate different sectors. LEADER in general supports inclusion of different sectors into the process of strategy design. Although due to the narrow orientation of some measures, this inclusion is often complicated. Consequently, widening of the portfolio of eligible measures is not the only solution for solving the situation with low participation of diverse sectors in some projects implemented through LEADER. Dominant financial motivation of some sectors, which are not eligible for subsidies from LEADER, is another cause of the situation.

The rate of network creation between different parties (LAG and other organizations operating in the rural development) was the main factor during evaluation of networking.

LEADER creates the opportunity for creation and strengthening of links within the municipality and also between municipalities in the same territory but also among different actors directly or indirectly involved in the LAG.

The strength of these links differs and it is evaluated based on estimation whether this cooperation would continue in the future even in case, the LAGs will not exist. The study also helped to identify the conflict between support for networks creation, on the one hand, and strictly regulated public procurement on the other hand, which does not always enable participation of the local actors. Regarding this matter, the LAG managers must coordinate two problems and those are information gaining connected with feedback and the total inclusion of different actors. Even though, there are some efforts leading to awareness creation and better information, this should be even stronger and better targeted on the network enhancement. Within the legislative framework, there should be adopted an act on the public procurement, which would take into account the needs of the LEADER approach for strengthening the local networks.

When assessing cooperation, the rate of support for the cooperation activities (such as transfer of information, best practices and know-how) was observed. The cooperation was implemented through particular initiatives of different actors and territories. LAG strengthens these links and networks, which, with high probability, will be functioning also in the future and they will lead to further cooperation. Intensive cooperation helps in exchange of knowledge and experience within and outside of the LAG territory. Excessive bureaucratic burden prevents the development of cooperation. The fact, that beside the financial aspect, cooperation is also essential for the territory seems to be problematic. This problem can prevent the cooperation of partners with unequal financial support.

In order to clarify the fact that the LEADER approach is predominantly a method for development and not a method for financing, more emphasis should be put on communication and information tools. Beside that, the managing authority should strengthen technical and financial support for earlier and later phases of cooperation. This support should be in a form of lowering of administrative burden and creation of set of measures which LAGs and final beneficiaries would be able to implement. It is very important to continue in maintaining and widening of networks what supports and deepens the cooperation between all involved parties.

Enabling of innovation had to be assessed from two perspectives. Firstly, it was necessary to find out whether the LAG members and final beneficiaries clearly understand the term innovation. Consequently, it was observed, whether LEADER enables implementation of the innovative initiatives in the rural sector.

LAGs, in general, are interested in financing of the innovative projects, however, due to the lack of finance, time constraints and not well-understood concept of innovation, they are not always able to implement such projects.

National LEADER guidance does not clearly define the concept of innovation, neither the characteristics of an innovative project. Different definition of innovation can be confusing for LAG members and for final beneficiaries and they can distort the results of LEADER approach in the regions. In spite of openness of LAG members towards accepting innovative proposals, there are no concrete mechanisms for supporting innovative ideas within the calls for proposals and budgets. Weaker participation of younger inhabitants (up 
to 30 years old) in LAGs can lead to decrease of innovative proposals in the strategy and in the future projects. Narrow options for measures selection has also limiting effect on developing of innovative ideas.

Therefore, for better inclusion of innovations into LEADER implementation, it would be essential to create unified concept of understanding of innovation at the MA level and to seek definition of characteristics of innovation or to state some examples. Wider selection of supported measures would have a positive impact on innovation. Results reached in definition and promotion of innovations should be distributed among individual actors through dissemination activities. Enhancing of innovation could be also implied via call for proposals specifically oriented on innovative projects or young final beneficiaries.

\section{References}

1. EUROPEAN COMMISSION. 2006. LEADER Approach - basic guidlines [online], [cit. 2015-01-21]. ISBN 92-79-02058-7. Available online: http://ec.europa.eu/agriculture/rur/leaderplus/pdf/library/methodology/leader_approach_sk.pdf.

2. HRABOVSKÁ, Z. - VAL'OVSKÁ, Z. 2014. Regionálna ekonomika a rozvoj II. (Regional Economics and Development II.) (selected chapters). Košice: Univerzita Pavla Jozefa Šafárika v Košiciach, pp. 234. ISBN 78808152224.

3. JANKOVIČ, D. 2012.Territorial Approaches to Regional Rural Development. In Economics of Agriculture, no. 4/2012, pp. 675- 688. UDC: 332.122:338.43.

4. COUNCIL REGULATION (EC) No. 1698/2005 on Support for Rural Development by the European Agricultural Fund for Rural Development (EAFRD).

5. Rural Development Programme SR 2007 - 2013.

6. SHUCKSMITH, M., THOMSON, K. J., ROBERTS, D. 2005. The $\mathrm{CAP}$ and the regions - Territorial impact of the common agri- cultural policy. Oxfordshire: CABI Publishing.

7. TVRDOÑOVÁ, J. 2014. The Case study: „Ex post evaluation of Leader approach delivery" - Final report [online], [cit. 201501-12]. Available online: http://www.fesrr.uniag.sk/tl_files/ fesrr/documents/IMRD/IMRD\%20CS\%202014\%20-\%20 Final\%20Report.pdf.

8. VOLK, A.- BOJNEC, Š.. 2014. Local action groups and the LEADER co-financing of rural development projects in Slovenia. In Agricultural Economics, vol. 60, no. 8, pp. 364-375. ISSN 0139570X.

9. ZAJDA, K. 2014. Problems of functioning of Polish local action groups from the perspective of the social capital concept. In Eastern European Countryside, no. 20/2014, pp. 73 - 97. ISSN $2300-8717$.

\section{Contact address/ Kontaktná adresa}

Ing. Monika Bumbalová, PhD.

Department of Public Administration, Faculty of European Studies and Regional Development, Slovak University of Agriculture in Nitra,

Tr. A. Hlinku 2, 94976 Nitra,

e-mail: monika.bumbalova@uniag.sk

Ing. Ivan Takáč, PhD.

Department of European Policies, Faculty of European Studies and Regional Development, Slovak University of Agriculture in Nitra, Tr. A. Hlinku 2, 94976 Nitra, e-mail: ivan.takac@uniag.sk

Mgr. Martin Valach, PhD.

Centre of International Programmes, Faculty of European Studies and Regional Development, Slovak University of Agriculture in Nitra, Tr. A. Hlinku 2, 94976 Nitra, e-mail: martin.valach@uniag.sk

\section{Ing. Jela Turdoňová, PhD.}

Faculty of European Studies and Regional Development, Slovak University of Agriculture in Nitra, Tr. A. Hlinku 2, 949 76, e-mail: jelatvrdonova@gmail.com 